\title{
A metaphysical and neuropsychological assessment of musical tones to affect the brain, relax the mind and heal the body
}

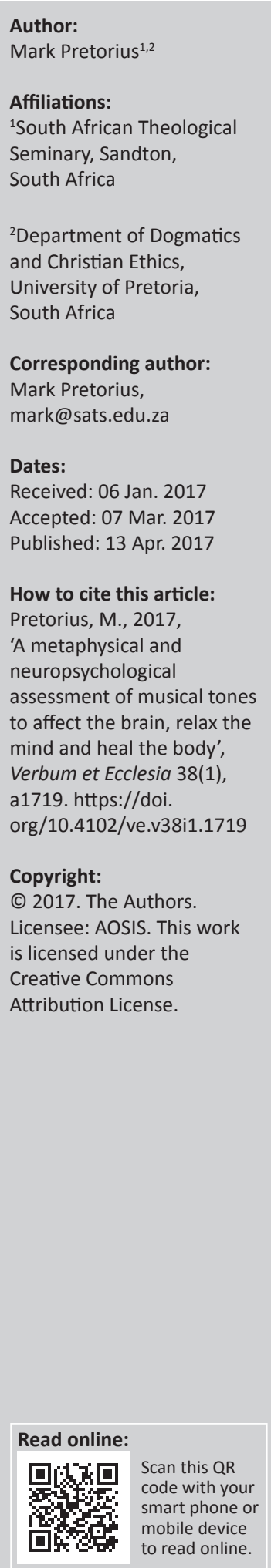

It has been empirically established through many controlled studies that one of the most rewarding experiences known to humanity is listening to music, especially because it affects various parts of the brain and causes emotional arousal. The aim of this article is to do a succinct study on music and its effect on, especially, the nervous system, by referring to various empirical studies undertaken on the subject. The article, therefore, has a twofold purpose: (1) to show that throughout history, music has played a special role in various cultures and religions, especially as a healing tool and (2) to demonstrate that sound frequencies and vibrations found in music have the potential to realign the emotions of the nervous system and bring the body back into harmony by reducing stress.

Intradisciplinary and/or interdisciplinary implications: The article's challenge and purpose are to show that science and religion are not in conflict, but rather that together they can benefit both disciplines and make better sense of complicated topics, especially those related to how natural science and religion deal with the human body and health, and its relationship to the mind.

\section{Introduction}

Few would doubt the enormous effect that music has on one's spiritual state of mind and body. In recent decades, research has shown the benefit of music to bring about spiritual and emotional wellbeing. Music has also been shown to enhance the senses, touch the emotions and create memories of specific events that one has experienced. McClellan (2000) further suggests that:

Music as a manifestation of energy, is a force that interacts with the physical world, for music influences our thoughts, our emotions, our dense physical bodies, and the electromagnetic field that surrounds us. (p. 4)

Music is also known to affect several parts of the brain, for example the hippocampus for memory, the amygdala for emotional reaction to music and the cerebellum which causes foot-tapping and dancing. Similarly, our brains inversely respond to happy, sad and scary music because music impacts on the autonomic nervous system. As presented by Ellis and Thayer (2010:317-362) the autonomic nervous system connects the central nervous system (brain and spinal cord) with the major peripheral organs and organ systems of the body, and thus the effect music has on the various organs of the body cannot be underestimated.

Studies now repeatedly show, as submitted by Leeds (2010:111), that music engages the brain at almost every level. Research by Chanda and Levitin (2013:179-193) and Raglio et al. (2015:68-78) confirm that music engages various areas of the brain, especially those involved in cognition, motivation, emotion and neuromotor functions. The term for these studies is now referred to as Musical Neuroscience or Cognitive Musicology, as proposed by Leeds (2010:16), Longuet-Higgins et al. (1994:103-113) and Vantomme et al. (1994:81). It is this awareness, amongst others, that this article seeks to uncover, including music's healing qualities.

The proposed model is to do a succinct narrative review of music's history as a physical and spiritual healing tool, and to explore briefly the intricacies of music as energy, including the symbiotic nature of the brain, the mind and music, to affect us mentally and physically, through an alignment of the energy within it. The article will also touch on the religious idea of music

Note: Please note that the author has included information from his previously published article entitled 'Sound: Conceivably the creative language of god, holding all of creation in concert' published by Verbum et Ecclesia, University of Pretoria. http://www.ve.org. za/index.php/VE/article/view/485. This article is a supplement to it. 
as a healing tool, to show expectantly that music is also able to affect us spiritually.

A part of the article will also deal with the issue of stress and its negative effect on the body. The idea is to show that music can calm the central nervous system and assist the body to maintain a steady state of physiological equilibrium, also known as bodily homeostasis. This allows the body a greater chance to heal from the effects of prolonged stress (see Van Deventer \& Mojapelp-Batka 2013:194). Here, empirical studies will briefly be referred to.

Naturally, one could argue against this proposal as a simple esoteric argument. But the purpose of this article is to show a promising scenario without being dogmatic and to present empirically verifiable evidence on what medical research has uncovered so far, including presenting a brief metaphysical basis for this promising scenario. One hopes that further scientific discoveries will advance the ideas presented here. In the author's 2011 article, and as referenced in the footnote, a succinct exegetical review was undertaken on the creation aspect of Genesis 1; therefore, the author believes it needs only briefly be repeated here.

\section{God's creative word, sound and energy}

As stated, the theory proposed is based on an article the author published in 2011. In it, the author advanced that the harmonic frequencies embedded within the initial light of God's spoken Word are still reverberating within the creation today. As a result, the hypothesis presented ostensibly maintains that all naturally occurring structures and shapes from the subatomic electron to the individual atomic elements, and from microscopic forms to planets, stars and galaxies - were formed and sustained by sound (vibrating energy) conveyed by light. Today, this is known as the SuperString Theory.

\section{According to Porter (2008):}

\begin{abstract}
In super string theory, the subatomic particles we see in nature are nothing more than different resonances of the vibrating superstrings, in the same way that different musical notes emanate from the different modes of vibration of a violin string. The forces between charged particles are the harmonies of the strings; the Universe is a symphony of vibrating strings. And when strings move in 10-dimensional space-time, they warp the space-time surrounding them in precisely the way predicted by general relativity. So strings simply and elegantly unify the quantum theory of particles and general relativity. (p. 40)
\end{abstract}

To further establish this from a physics perspective, light can and does exemplify waves. Also, Planck's equation affirms that besides being a quanta of energy, each photon also has a precise frequency and wavelength allied to it (see Kotz, Treichel \& Townsend 2009:273). This is made clear in Planck's equation $E=h v$ : $E$ (energy) $=V$ (wavelength) $H$ (Planck's constant) of the proton (cf. Encyclopedia Britannica 2016). In essence, his formula shows that atoms - the building blocks of matter - vibrate at different frequencies (some high and some low) and that they emit light. From a biblical perspective, the following should also be considered.

\section{A theology of sound}

Theologically, one could offer that God used light and sound to construct the universe, and these still resonate within the universe, now holding creation together. For example, if one looks at Genesis 1:1 from this perspective, one sees that there appears to be value on sound and expression specifically. The following scriptural references are purely selected to show that God spoke. The author seeks nothing further from these verses:

- Genesis 1:1 'In the beginning God created the heavens and the earth'. Everything within the universe (or multiuniverse) is included in these 10 words. Further, each day of the creation week begins with, 'And God said (or voiced a sacred sound) ...'

- Psalms 33: 6 says, 'By the Word of the Lord were the heavens made; and all the host of them by the breath of his mouth'.

- Hebrews 1:3f. 'Who being the brightness of his glory, and the express image of His person, and upholding all things by the word (or sacred sound) of his power ...'

Scripture is unambiguous that not only did God create the world and all within in it by his Word, but that he still preserves it through his Word now. In other words, over and above the 'that', we meet to a certain extent the 'how' of creation too!

One could advance this metaphor and propose that not only are we dealing with a universe brought into subsistence and sustained by light and sound, but that these sounds are harmonical frequencies, arranged by God to bring into being certain structures and forms, that is, the creation that we see today (Gn 1:31).

To further support this, and as mentioned in the author's previous article, Keil and Delitzsch's (1973:46-47) understanding of Genesis 1:1 assumes there was no matter when God first spoke:

And the earth was (not became) waste and void. The alliterative nouns tohu vabohu, the etymology of which is lost, signify waste and empty (barren), but not laying waste and desolating. Whenever they are used together in other places (Isa 34:11; Jer $4: 23)$, they are taken from this passage; but tohu alone is frequently employed as synonymous with ㅉ?, non-existence, and לִּקה nothingness. (Isa 40:17, 40:23, 49:4)

Hebrews 11:3 further implies that God formed the worlds with no pre-existing matter or energy (ex nihilo). It is thus the author's contention that this verse shows that because the basic units of matter are too small to see, that is, not visible to the naked eye, it may refer to the building blocks of matter according to Pommerville (2009:42-43), such as atoms, protons, neutrons, electrons, energy and the different 'waves' 
that one cannot observe. Hebrews 11:1 could - according to the assertions that will follow - possibly read:

God used faith (substance) and the word (energy) to create the universe. He spoke (sound/vibration/light) and His Words released (caused) the substance that became the stars and planets, and all we see today.

In line with this, Cady (2009:6-7) justly states that God is spirit (Jn 4:24), that is $\pi v \varepsilon v \tilde{\mu} \alpha$ ó $\theta \varepsilon o ́ c$. Meaning, God has no tangible existence. He is the Creative Energy which is the cause of all visible things. God as Spirit is the invisible life and intelligence which underlies all physical things. There could be no body of visible part to anything unless there was first spirit as creative cause.

The question, therefore, proposed and settled in that article was:

Do sound frequencies and vibrations have the potential to create, and is it theologically sagacious to assert that God was the ultimate source of that sound embedded within the initial light of His spoken Word, specifically sacred sound, bringing into existence reality as presently observed? (see Pretorius 2011:n.p.)

The author further proposed that sound was, and is, one of the mediums employed by God in creating, providing and keeping his creation together (see Col 1:17; Heb 1:3), and that if we live in a universe influenced and kept in concert by sound frequencies, could one impose sound to bring about healing, order and balance to the human body? (cf. Pretorius 2011). This would include the awareness that our bodies consist of atoms, which in turn is vibrating energy. This is important to recognise because the flow of this article rests on the understanding that the human body is energy, and energy vibration plays an important role in health and disease (see Lipton 2008:72). In this sense, the author would like to refer to the Kybalion, to further strengthen the idea of vibrational energy.

\section{The Kybalion and the law of vibration}

The Kybalion, first published by the Three Initiates in 1908 through the Yogi Publication Society, and later by Atkinson (2011), are philosophical and religious writings commonly attributed to Hermes Trismegistus, which, proclaims Wallis-Budge (1969 [1904]:414-415) is often considered to represent a synthesis of the Greek god Hermes and the Egyptian god Thoth. As proposed by Heiser (2011), during both the Renaissance and the Reformation periods, these writings were considered important. Traditions further claim, according to Yates (1991:433-434), that the book descends from a prisca theologia, a doctrine, states Hanegraaff (1997:360), asserting that '... a single true theology exists, which threads through all religions and was given by God to humanity in antiquity'. Each chapter of the book is devoted to its seven 'Principles', or axioms, but it is the third principle that is of interest to the author, as it deals with The Principle of Vibration (Atkinson 2011:36). It proposes the idea that
'... motion is manifest in everything in the universe, that nothing rests, and everything moves, vibrates, and circles' (Atkinson 2011:66). It further proposes, and as presented by the author of this article, that atoms and their elements are vibrating energy (Atkinson 2011:136).

Although the Kybalion writings have a rich mythical foundation, mixed with traditional religious and philosophical thought, empirical evidence nevertheless shows and confirms that when the human body is broken specifically down to its fundamental elements, it consists of energy vibrating at certain harmonic frequencies. This would include the chemical compounds that cause the body to react in various ways, depending on which chemicals are released into the body, and in what quantity. One may well link this to Pert's (1997:177-178) assertion that 'cells are biochemical factories that generate behavioural chemicals which can yield peaceful, restful, calm behaviour or angry destructive behaviour'. In this case, music can be used as a tool to affect emotion, modulate mood and evoke powerful responses. The article will briefly attempt to uncover how sound (music in this case) is converted into nerve energy frequencies, which affect the nervous system of the body in several ways, through the release of these various behavioural chemicals.

\section{To advance this, Aluede and Ekewenu (2009) propose:}

Ever since the creation of the universe, music has had a tremendous effect on mortals. This accounts for the reason why music has been accepted in healing singularly or incorporated in healing rituals in most communities of the world. (p. 162)

Interestingly, in the late 1920s according to Goldman (2002:33), Hans Kayser, a German scientist, believed the 'whole number ratios of musical harmonics correspond to an underlying framework existing in chemistry, physics, crystallography, astronomy, architecture, spectroanalysis, botany, and other natural sciences'. He further states the relationship experienced in the periodic table of elements, and an understanding of matter forming, resembles the overtone structure of music. Goldman (2002:25) also upholds that even when it comes to tuning instruments, it can be complex. Differences in tuning, he states, have to do with mathematics. What is most important to realise about harmonics or overtones, says Goldman (2002:28), is that they mathematically interrelate.

Indeed, the science of harmonics, says Goldman (2002:38), has revealed a phenomenon of sound that has applications in most fields of the natural sciences. Admittedly, the power of energy and its relationship to the mathematical equations found in harmonic frequencies to change and organise matter are far from complete. Fortunately, significant studies are emerging on this issue. What follows is a discussion on what current research is uncovering on music's effect on the brain, especially what neuroscience now reveals on its healing potential. The author will begin with a brief historical introduction to music as a healing tool. 


\section{A brief historical introduction to music as a spiritual and physical healing tool}

The idea that music can and does affect us neurologically and spiritually in positive ways to bring about healing if rightly presented is historically well documented. For example, many great figures of antiquity such as Galileo, Orpheus and Pythagoras, writes James (1995:99), offer 'evidence through their extensive body of classical literature, asserting the miraculous power of music to move the spirit, heal the body, and influence sublunary affairs'. Music, according to Misic et al. (2010:839), ' $\ldots$ has been a medium of therapy for centuries, and there are many examples of the curative or healing powers of music in the historical records of different cultures'. In Musica Humane, for example, Pythagoras - the Greek philosopher and mathematician - suggested that there is harmony or inharmonious resonance (harmonic frequencies) between soul [mind] and body [brain] (cf. James 1995:31). Further, Plato, regarded as one of history's most influential philosophers, stated, as referenced by Carroll (2011:171-178), that 'Music is medicine to the soul' and 'Through music, the soul learns harmony and rhythm and even a disposition to justice' (cf. Thompson 2014:130-131).

Moreover, Ellis and Thayer (2010:317-326) uphold that 'Physiological investigations of music date back over 125 years'. They further present that Diserens (1926:129-154), a past lecturing psychologist at Cincinnati University, cites some 24 investigations between 1880 and 1918 alone, on the physiological effects of music. Similarly, they advance that 'Nearly every organ in the body with an electrical, chemical, or volumetric signature has at some point been investigated in conjunction with musical stimuli' (1926:154) (cf. Bartlett 1996:343-385; Hodges 1980a:393-400; Hodges 1980b:279-311). As further offered by Meymandi (2009):

Since ancient times, music has been recognized for its therapeutic value. Greek physicians used flutes, lyres, and zitters to heal their patients. They used vibration to aid in digestion, treat mental disturbance, and induce sleep. Aristotle (323-373 BCE), in his famous book De Anima, wrote that flute music could arouse strong emotions and purify the soul. Ancient Egyptians describe musical incantations for healing the sick. (pp. 43-45)

Meymandi's (2009) study further shows that:

Researchers began systemically to study the application of music in medicine and healing near the end of the 19th century. Studies reporting the effects of music on physiological responses, such as cardiac output, respiratory rate, pulse rate, and blood pressure (BP), were originally reported by Diogel (late 1700s) of Salpetriere Hospital in Paris. (pp. 43-45)

It is evidently clear that over the centuries, music has held a special place in civilisation. The quandary, according to Wimberly (1997:103), is that insignificant consideration is assigned to the spiritual and physical healing power of especially, religious songs. Music, as a vehicle for selfempowerment and spiritual wellbeing, can be found in the traditions of many cultures yet often ignored in contemporary societies. For example, Bealieu (1987) writes:
In India, it is said that the universe hangs on sound. Not ordinary sound, but a cosmic vibration so massive and subtle and allencompassing that everything seen and unseen (including man) is filled with it. (p. 35; see also Reck 1997:7)

The sacred sound referred to here, as presented by Lochtefeld (2002:482), is called Om or Aum. It is considered a spiritual symbol and a vibrational mantra in all Indian religions and allegedly encompasses all words and sounds in human language, including music. As presented by Bealieu (1987) and Reck (1997), it is regarded as the basic (vibrational) sound of the universe.

Nevertheless, there is significant movement towards understanding the healing power of music. To employ the words of Scarantino (1987:73), 'Music works. It soothes. It comforts. It reaches deep down and touches us on a biological and emotional level, including on a spiritual level'. To complement this, Wimberly (1997) stresses:

Whether physical, psychological, relational or spiritual, healing is a dynamic and mysterious process that happens. It is given by God who created us and who seeks to help us arrive at healing and wholeness. (p. 104)

Therefore, and as further argued by Wimberly (1997:100), the use of music to promote healing is not new, 'Healing shrines and temples of old employed hymn specialists and prescribed music for the emotionally ill'. In ancient Greek culture, as stated by Goldman (2002):

... the god Apollo was god of both music and medicine. There were healing temples which focused on music as the main force for harmonising the body and spirit, thus affecting cures. (p. 28)

One also finds that music, in particular, was employed in various instances to heal and deliver people in biblical times. As expressed by Meymandi (2009:43-45) there are hundreds of references to music throughout the Old and New Testaments. For example, David's use of the harp to soothe the madness of Saul (see 1 Sm 18:10). LeAre (1981:11) also rightly indicates that 'on the toughest night of His life, before going out into the garden of Gethsemane, Jesus and His disciples sang a hymn' (Mt 26:30). One could rightly argue that singing, for example, is the way the body harmonises itself and brings calmness and peace to troubled minds. For example, McClellan (2000) maintains:

\footnotetext{
Singing regulates, sustains and deepens the breath, increases the sensitivity of auditory system and refines the internal sensing process. Singing can resonate the entire physical body and the electro-magnetic field, fully engage the mind, and give the emotions a vehicle for expression and produce an overall sense of wellbeing. When we combine the singing of sustained pitches with specific vowels and directed concentration we can, in addition, revitalise our internal organs, tone our endocrine gland system and calm our nervous system. (p. 71)
}

On this Musicologists agree, because they state, as expressed by Pereira et al. (2011), that music is a form of language or communication that directly accesses the emotions, with or without intermediating words and rational thought. 
The question now is: how does music promote healing, especially towards stress and anxiety?

\section{The efficacy of music to reduce stress}

Music therapy has an empirically demonstrated efficacy as an independent treatment for reducing stress, the major cause of depression (see Chan, Wong \& Thayala 2011:332-348), anxiety (see Li et al. 2011b:1145-1155) and pain (see Li et al. 2011a:411-419). As revealed, music evidently has special characteristics which exert positive or negative effects on people, by stimulating the autonomic nervous system and central nervous system. How this is achieved will now be further advanced.

Music's rich history as a healing tool was briefly unveiled, to reveal its importance in human structure, and show that in a sense it is the physical part of the spiritual. Unlike many other stimuli, music can often evoke emotions spontaneously without external associations. Music, as the 'carrier wave', can bring the human body's inharmonious chemicals back into harmony (order to chaos and conflict), thus reducing stress and related emotions, which are the major cause of sickness. In this case music, as a tool, can be used to affect emotion, alter mood and arouse intense biological responses.

Further, and as presented by Leaf (2013:33), 'Research shows that 75 to 98 percent of mental, physical, and behavioural illness comes from one's thought life'. She further states, 'This staggering and eye-opening statistic means only 2 to 25 percent of mental and physical illnesses come from the environment and genes' (Leaf 2013:34). Stress, according to Slavich and Cole (2013:331-348), can slow the healing of wounds and weaken the immune system, making infections and disease more dangerous. In fact, according to Bauer (2003):

Stress and depression change the activity of genes not only in numerous immune messenger substances (cytokines), but also within the cells of the immune system (for example T-cells and natural-killer cells). (pp. 84-88) ${ }^{1}$

Interestingly, diseases within a human body, according to Beck (2007:69), may also express an internal disharmony that has to do with one's (unconstructive) relationship with God. Disharmony of this kind negatively affects the immunological system and influences one's genes. On this, Slavich and Cole (2013:331-348) conclude that the impact of stress on health can be mapped to genetic changes and the brain, as will now briefly be explored.

\section{Music and its effect on the brain and nervous system}

Our brains consist of billions of neurons that affect our bodies in ways we often fail to realise, and this relates strongly to

\footnotetext{
1.Known as Cytotoxic Tlymphocyte cells, these cells attack viruses that hide and grow inside infected cells. They are activated by T cells (T lymphocyte cells) to help return the immune system to normal.
}

what we meditate on. As presented by Fernandez, Goldberg and Michelon (2013):

Neurons have a specialised ability to manage bioelectrical information and to communicate with one another by exchanging chemical information in the form of neurotransmitters (for example dopamine and serotonin) through connections with other neurons known as synapses. (p. 19)

Moreover, Stebnicki (2008:64-65) submits, our brains also consist of a phenomenal mass of neural pathways connecting each neuron which affect our bodies (positively or negatively). The more we use each neural pathway, the more entrenched they become. Similarly, the more we listen to certain music, the emotional effect it has on us becomes entrenched within these neural pathways. Further, and according to an intensive study conducted by Logeswaran and Bhattacharya (2009:129), 'Music is one of the most powerful elicitors of subjective emotion ...' The study showed that after hearing a short piece of music, participants were more likely to interpret a neutral expression as happy or sad, to match the harmonic frequencies of the music they heard. In this case, a neural pathway has been created, so when the music piece is played, it elicits a chemical reaction within the body, causing an emotional and physical response. Conversely, the ear plays an important part. The inner hair cells or nerve receptors in the ear are essential because they translate sound or the vibrations they receive into electrical nerve impulses. These are sent to auditory nerves connecting the inner ear to the brain. Essentially, these trigger the release of neurotransmitters at the basal end of the cell. Neurotransmitters are the brain chemicals that send information throughout the brain and body, and amongst other causes, affect mood and sleep.

Here, a recent study by Salimpoor et al. (2011:257-262) discovered that a neurotransmitter identified as endogenous dopamine is released in the striatum at peak emotional responses to pleasant music. Thus, as put forth by Leaf (2013:47-48), whatever we meditate on and listen to (in this case music) creates electromagnetic and electrochemical actions in our neurons. Leaf further maintains that it causes various 'genetic expressions' within our bodies that can and do affect us positively or negatively.

Further, the following empirical studies show how music affects and brings about healing and comfort to various ailments:

- When it comes to severe pain, such as rheumatoid and arthritis, music has shown to help reduce the pain by up to $21 \%$ and depression by up to $25 \%$ (see Siedliecki \& Good 2006:553-562).

- To reduce the need for medication during childbirth, hospitals are progressively using music therapy because it has been found to reduce post-operative pain and complements the use of anaesthesia during surgery (see Nilsson, Unosson \& Rawal 2005:96-102). 
- It has also been determined that music reduces high blood pressure (see Teng, Wong \& Zhang 2007:4649-4651).

- Music has also shown to relax one's heart rate and brings about calmness, thus reducing stress (see Bernardi, Porta \& Sleight 2006:445-452).

- Similarly, studies have not only revealed that music speeds up the recovery of patients who have suffered a stroke, but has shown to induce fine-grained neuroanatomical changes in the recovering brain of the stroke victim (see Särkämö et al. 2008:866-876, 2014:245).

- For migraine and chronic headache sufferers, music has benefited them by reducing the intensity and frequency of them (see Oelkers-Ax et al. 2008:301-313; Risch, Scherg \& Verres 2001:116-125).

Seemingly, there is inherent power in music to bring about spiritual and physical healing within the human body. However, the author is persuaded that this healing 'energy' relates to God's initial spoken Word. Therefore, one can settle that God is the initial source of this energy, and uses - at his sole discretion - secondary sources such as music, for example, to keep his creation, where possible, functioning as he desires.

The procedure of sound, therefore, and how it stimulates the body, is referred to by Van Deventer and Mojapelp-Batka (2013:297) as stimulus energy. For the brain to cognise stimulus energy, the nerve receptors in the ear (as discussed) have to convert sensory messages such as sound into electrical nerve impulses, which the neurons then carry to the brain in a form it can understand. The transformation of one form of energy to another is called Transduction (Van Deventer \& MojapelpBatka 2013:296). Expressly, the sensory receptor cells convert or transduce sensor (stimulus) energy into nerve energy, which affects the nervous system of the body in various ways. But the question now is, how does this work in practice? What follows are references to empirical studies conducted over several years, to show the effects of music and its healing potential.

\section{Neuroscience and harmonic frequencies}

As presented by Leeds (2010), a sound researcher, educator and music producer:

The quantum leap in understanding music and the nervous system, and the ability to administer precise frequencies for specific physiological applications, comes forward through high technology advances of electroencephalography (EEG) recordings of electrical activity along the scalp produced by the firing of neurons within the brain - and through the invention of magnetic resonance imaging (MRI). (p. 90)

Neuroscience further informs us that not only are our brains flexible to change - a term called neuroplasticity - but that this change especially happens when listening to music which as presented, are complicated mathematical harmonic frequencies which, when converted to energy, affect the human body in various ways. For instance, Watanabe (2012) claims:
Music has the ability to spark memories and evoke powerful emotions. The past decade has seen an exponential increase in studies of music and emotion. So far, most studies exploring the psychological and neural basis for the impact of music on our emotions have focused on perception, induction, and recognition of basic emotions, such as happiness and sadness. (pp. 14971498; see also Pereira et al. 2011)

Emotional and physical changes - specifically when listening to music - are repeatedly studied (see Ekman 1999:45-60). The methods used to establish the effect of music on emotions were questionnaires (see Krumhansl 1997:336-353), and by testing the effect of music on patients with brain lesions (see Peretz, Gaudreau \& Bonnel 1998:884-902). Tests were also conducted by documenting how the autonomic nervous system reacts to music (see Khalfa et al. 2002:145-149; Krumhansl 1997:336-353), and by measuring central nervous system responses to music (see Khalfa et al. 2005:1981-1984; Mitterschiffthaler et al. 2007:1150-1162).

Through these meticulous studies, scientists now have empirical evidence that shows that the human brain reacts to music (harmonic frequencies) in various ways and relays this to different parts of the human body by transduction, to create, as previously explained, a positive or negative chemical response. One of the positive ways is that certain musical vibrations may realign the chemical imbalances within the human body and bring about healing for certain maladies (see Akiyama \& Sutoo 2011:58-60). Here, Gaynor (2002) makes a profound statement about the healing power of music, and he states:

Sound is a uniquely potent form of energy medicine that entrains us to the vibrations of our own essence and that of the Universe. Sound is also the simplest, most direct route I know to achieve the sense of profound calm that allows us to move into that peaceful inner place, that I call our essence. (p. 189)

Conversely, listening to music that promotes negative chemical responses can cause our bodies stress and harm. For instance, in studies conducted by Zhang et al. (2012:15731578), they show that negative, or 'frightening', music can quickly provoke negative emotions in listeners. They did this by investigating monoamine receptor changes induced by frightening music. Undoubtedly, and as expressed so far, music as a tool to communicate emotion and modulate mood can arouse powerful reactions. Unlike many other stimuli, music can often and unexpectedly stimulate various emotions in the absence of external associations (cf. Blood et al. 1999:382-387).

\section{Music and its healing potential}

As presented so far, and in reference to the author's previously published article on the subject, God's Word sent forth at the beginning of time contained all the elements to not only create the universe, but so too the human body, and to a certain extent keep it healthy. It was also shown that atoms, from which all matter is made, including the human body, is vibrating energy, Langenberg (2013) states: 
Everything physical - everything made of matter - is actually vibrating energy. That is what Albert Einstein's famous equation $E=m c^{2}$ square means. Matter is slowed-down, smushed together, 'crystalized' light. He goes on to state 'Like transceivers, our brains process energy. Every thought is an electromagnetic wave, and each thought travels at its own unique frequency. Thoughts especially emotionally driven thoughts - combine with other thoughts vibrating at the same frequency. All living creatures constantly emit physical, emotional and mental vibrational waves, and we receive at the frequency at which we are vibrating'. (pp. 10-11)

It was also specified in the beginning that everything in the universe is in a vibrational state, including the human body. Goldman (2002) upholds that:

Every organ, bone, tissue and other parts of the body has a healthy resonance. When that frequency alters, that part of the body vibrates out of harmony, and this is what is termed disease. If it were possible to determine the correct resonant frequency for a healthy organ, and then project it into that part which is diseased, the organ should return to its normal frequency and a healing should occur. (p. 90)

To take this deeper, and as presented so far, one could say that not only did God's creative Word structure the universe, nature and humankind, but it contains all the elements, especially harmonic frequencies within the atoms found within the various chemical elements of the body, to keep it healthy. Harmoniously then, if the correct sound waves or harmonic frequencies in certain types of music are appropriately directed to those atoms that make up the chemical components within our bodies that are harmonically out of synchronisation through stress and disease, it may bring about the needed healing. It achieves this through adjusting the necessary inharmonious atomic frequencies that comprise the human body, back to the right frequencies, as presented by Goldman (2002:90). On this, a substantial body of clinical data, according to Clark, Downey and Warren (2014:444-452), has now been amassed, showing the positive effects of music on the structural and emotional processors in developmental and acquired brain disorders, including autism (see Allen, Hill \& Heaton 2009; Allen, Walsh \& Zangwill 2013; Caria, Venuti \& De Falco 2011), strokes and other focal lesions (see Griffiths et al. 2004; Jacome 1984; Satoh et al. 2011). The study also included the impact music has on neurodegenerative diseases (see Downey et al. 2013; Drapeau et al. 2009; Hailstone, Omar \& Warren 2009; Omar et al. 2011).

As was shown by referring to several empirical studies throughout this article, there is growing scientific evidence showing that the brain and spirit respond to music in very specific ways. This has led researchers to carefully and meticulously explore this area to experimentally validate that musical tones, absorbed through the body, can help relax the nervous system and thereby ease pain and, in several cases, help restore the body to health. To date, and as submitted, empirical evidence is yielding positive results. There is little doubt in the author's mind concerning the efficacy of music on the brain and body to aid healing and spiritually revitalise a person. At its very essence music is sound, and sound is rooted in vibration, which as proposed is related to God's initial spoken Word in Genesis 1.

\section{Conclusion}

At the beginning of this article, it was shown that music had an immense effect on one's state of mind, and that it could be effectively used as a healing tool, when properly directed and managed. It was further stated that the universe, including the entire creation, was in a state of vibration. Here, it is shown that every sound has a physical effect upon the body, and that sound is, as a consequence, very important because it is the physical part, in a sense, of the spiritual. It is comprehensible then that, as a secondary cause, it possesses through the ultimate cause, God, the ability to bring about healing within the human body. Various empirically verified medical studies were presented to establish the healing potential of sound, specifically music.

However, the numerous ideas presented here are not an attempt to prove that one could live pain free and continually remain healthy through the application of music or sound therapy. The law of entropy still governs all matter, and we need to be reminded that we do live in a world that is broken and dying. As such, the overall intent of this article was to rather demonstrate that sound frequencies and vibrations found in music have the potential to realign the emotions of the nervous system, and bring the body back into harmony by reducing stress. By this, we can minimise how quickly our bodies degenerate and thereby live a better quality of life through controlling stress levels and the various maladies associated with stress, thus allowing the body's own immune system to function at its peak. It must be noted that music is but one of the ways that this can be achieved.

\section{Acknowledgements}

Support for this project was provided through the Issachar Fund Sabbatical Writer's Retreat.

\section{Competing interests}

The author declares that he has no financial or personal relationships that may have inappropriately influenced him in writing this article.

\section{References}

Akiyama, K. \& Sutoo, D., 2011, 'Effect of different frequencies of music on blood pressure regulation in spontaneously hypertensive rats', Neuroscience Letters 487(1), 58-60. https://doi.org/10.1016/j.neulet.2010.09.073

Allen, R., Hill, E. \& Heaton, P., 2009, 'The subjective experience of music in autism spectrum disorder', Annals of the New York Academy of Sciences 1169(1), 326-331. https://doi.org/10.1111/j.1749-6632.2009.04772.x

Allen, R., Walsh, R. \& Zangwill, N., 2013, 'The same, only different: What can responses to music in autism tell us about the nature of musical emotions?', Frontiers in Psychology 4, 156. https://doi.org/10.3389/fpsyg.2013.00156

Aluede, C.O. \& Ekewenu, D.B., 2009, 'Healing through music and dance in the Bible: Its scope, competence and implications for the Nigerian music healers', EthnoMedicine 3(2), 159-163.

Atkinson, W.W., 2011, The Kybalion: The definitive edition, P. Deslippe (ed.), TarcherPerigee Publications, New York. 
Bartlett, D.L., 1996, 'Physiological responses to music and sound stimuli', in D.A Hodges (ed.), Handbook of music psychology, 2nd edn., pp. 343-385, IMR Press, Hodges (ed.), $\mathrm{HX}$
San Antonio, TX.

Bauer, T., 2003, 'Das Messequartier der Brüder Kannengiesser aus Köln in Frankfurt am main, ein Mietvertrag aus dem Jahre 1560', Jahrbuch des Kölnischen Geschichtsvereins 62(1), 84-88. https://doi.org/10.7788/jbkgv.1991.62.1.84

Bealieu, J., 1987, Music and sound in the healing arts, Station Press, New York.

Beck, M., 2007, 'Illness, disease and sin: The connection between genetics and spirituality', Christian Bioethics 13(1), 67-89. https://doi.org/10.1080/138036 00701283052

Bernardi, L., Porta, C. \& Sleigh, P., 2006, 'Cardiovascular, cerebrovascular, and respiratory changes induced by different types of music in musicians and nonmusicians: The importance of silence', Heart 92(4), 445-452. https://doi org/10.1136/hrt.2005.064600

Blood, A.J., Zatorre, R.J., Bermudez, P. \& Evans, A.C., 1999, 'Emotional responses to pleasant and unpleasant music correlate with activity in paralimbic brain regions', Nature Neuroscience 2(4), 382-387. https://doi.org/10.1038/7299

Cady, E., 2009, Lessons in truth, Biblio Bazaar, Charleston, SC.

Caria, A., Venuti, P. \& de Falco, S., 2011, 'Functional and dysfunctional brain circuits underlying emotional processing of music in autism spectrum disorders', Cerebral Cortex 21(12), 2838-2849. https://doi.org/10.1093/cercor/bhr084

Carroll, D., 2011, 'Historical roots of music therapy: A brief overview', Revista do Núcleo de Estudos e Pesquisas Interdisciplinares em Musicoterapia (NEPIM) 2, 171-178.

Chan, M.F., Wong, Z.Y. \& Thayala, N.V., 2011, 'The effectiveness of music listening in reducing depressive symptoms in adults: A systematic review', Complementary Therapies in Medicine 19(6), 332-348. https://doi.org/10.1016/j.ctim.2011.08.003

Chanda, M.L. \& Levitin, D.J., 2013, 'The neurochemistry of music', Trends in Cognitive Sciences 17(4), 179-193. https://doi.org/10.1016/j.tics.2013.02.007

Clark, C.N., Downey, L.E. \& Warren, J.D., 2014, 'Brain disorders and the biological role of music', Social Cognitive and Affective Neuroscience 10(3), 444-452. https://doi. org $/ 10.1093 /$ scan $/$ nsu079

Diserens, C.M., 1926, The influence of music on behavior, Princeton University Press, Princeton, NJ.

Downey, L.E., Blezat, A., Nicholas, J., Omar, R., Golden, H.L., Mahoney, C.J. et al., 2013 'Mentalising music in frontotemporal dementia', Cortex 49(7), 1844-1855. https://doi.org/10.1016/j.cortex.2012.09.011

Drapeau, J., Gosselin, N., Gagnon, L., Peretz, I. \& Lorrain, D., 2009, 'Emotional recognition from face, voice, and music in dementia of the Alzheimer type', Annals of the New York Academy of Sciences 1169(1), 342-345. https://doi. org/10.1111/j.1749-6632.2009.04768.x

Encyclopedia Britannica, 2016, Planck's constant, Ultimate Reference Suite, Encyclopedia Britannica, Chicago, IL.

Ekman, P., 1999, 'Basic emotions', in T. Dalgleish \& M. Power (eds.), Handbook of cognition and emotion, John Wiley \& Sons, Ltd, Sussex, 45-46.

Ellis, R.J. \& Thayer, J.F., 2010, 'Music and autonomic nervous system (dys)function', Music Perception 27(4), 317-326. https://doi.org/10.1525/mp.2010.27.4.317

Fernandez, A., Goldberg, E. \& Michelon, P., 2013, The SharpBrains guide to brain fitness: How to optimize brain health and performance at any age, SharpBrains, Washington, DC.

Gaynor, M., 2002, The healing power of sound: Recovery from life-threatening illness using sound, voice, and music, Shambhala, Boulder, CO.

Goldman, J., 2002, Healing sounds: The power of harmonics, Healing Arts Press, Rochester, VT.

Griffiths, T.D., Warren, J.D., Dean, J.L. \& Howard, D., 2004, 'When the feeling's gone: A selective loss of musical emotion', Journal of Neurology, Neurosurgery, and Psychiatry 75, 344-345. https://doi.org/10.1136/jnnp.2003.015586

Hailstone, J.C., Omar, R. \& Warren, J.D., 2009, 'Relatively preserved knowledge of music in semantic dementia', Journal of Neurology, Neurosurgery, and Psychiatry 80(7), 808-809. https://doi.org/10.1136/jnnp.2008.153130

Hanegraaff, W.J., 1997, New age religion and Western culture, SUNY Press, New York.

Heiser, J.D., 2011, Prisci Theologi and the Hermetic Reformation in the Fifteenth Century, Repristination Press, Bynam, Texas.

Hodges, D.A., 1980a, 'Physiological responses to music', in D.A. Hodges (ed.), Handbook of music psychology, pp. 393-400, National Association for Music Therapy, Lawrence, KS.

Hodges, D.A., 1980b, 'Psychophysiological responses to music', in P.N. Juslin \& J.A. Sloboda (eds.), Handbook of music and emotion: Theory, research, applications, pp. 279-311, Oxford University Press, New York.

Jacome, D.E., 1984, 'Aphasia with elation, hypermusia, musicophilia and compulsive whistling', Journal of Neurology, Neurosurgery \& Psychiatry 47(3), 308-310. https://doi.org/10.1136/jnnp.47.3.308

James, J., 1995, The music of the spheres: Music, science, and the natural order of the universe, Springer Publishers, New York.

Keil, K. \& Delitzsch, F., 1973, Pentateauch, 3 vols, Biblical commentary on the Old Testament, Eerdmans, Grand Rapids, MI.

Khalfa, S., Peretz, I., Blondin, J. \& Manon, R., 2002, 'Event-related skin conductance responses to musical emotions in humans', Neuroscience Letters 328(2), 145-149.

Khalfa, S., Schon, D., Anton, J.L. \& Liégeois-Chauvel, C., 2005, 'Brain regions involved in the recognition of happiness and sadness in music', NeuroReport 16(18), 1981-1984. https://doi.org/10.1097/00001756-200512190-00002
Kotz, J.C., Treichel, P. \& Townsend, J.R., 2009, Chemistry and chemical reactivity, vol. 2, Cengage Learning, London.

Krumhansl, C.L., 1997, 'An exploratory study of musical emotions and psychophysiology', Canadian Journal of Experimental Psychology 51(4), 336-353. https://doi.org/10.1037/1196-1961.51.4.336

Langenberg, M., 2013, Quantum god: How life really works, Balboa Press, Bloomington, IN.

Leaf, C., 2013, Switch on your brain: The key to peak happiness, thinking, and health, Baker Books, Grand Rapids, MI.

LeAre, T., 1981, Faithsong: A new look at the Ministry of music, The Westminster Press, Philadelphia, PA.

Leeds, J., 2010, The power of sound: How to be healthy and productive using music and sound, Healing Arts Press, Rochester, VT.

Li, X.M., Yan, H., Zhou, K.N., Dang, S.N., Wang, D.L. \& Zhang, Y.P., 2011a, 'Effects of music therapy on pain among female breast cancer patients after radical mastectomy: Results from a randomized controlled trial', Breast Cancer Research and Treatment 128(2), 411-419. https://doi.org/10.1007/s10549-011-1533-z

Li, X.M., Zhou, K.N., Yan, H., Wang, D.L. \& Zhang, Y.P., 2011b, 'Effects of music therapy on anxiety of patients with breast cancer after radical mastectomy: A randomized clinical trial', Journal of Advanced Nursing 68(5), 1145-1155. https://doi. clinical trial', Journal of Advanced Nur
org/10.1111/j.1365-2648.2011.05824.x

Lipton, B.H., 2008, The biology of belief: Unleashing the power of consciousness, matter \& miracles, Hay House, London.

Lochtefeld, J., 2002, Om, the illustrated Encyclopedia of Hinduism, Vol. 2: N-Z, Rosen Publishing, New York.

Logeswaran, N. \& Bhattacharya, J., 2009, 'Crossmodal transfer of emotion by music' Neuroscience Letters 455(2), 129-133. https://doi.org/10.1016/j.neulet.2009.03.044

Longuet-Higgins, H.C., Webber, B., Cameron, W., Bundy, A., Hudson, R., Hudson, L. et al., 1994, 'Artificial intelligence and musical cognition [and discussion]', Philosophical Transactions of the Royal Society A: Mathematical, Physical and Engineering Sciences 349(1689), 103-113. https://doi.org/10.1098/rsta.1994.0116

McClellan, R., 2000, The healing forces of music: History, theory, and practice, iUniverse, Bloomington, IN.

Meymandi, A., 2009, 'Music, medicine, healing, and the genome project', Psychiatry (Edgmont) 6(9), 43-45.

Misic, P., Arandjelovic, D., Stanojkovic, S., Vladejic, S. \& Mladenovic, J., 2010, 'P02-216 - Music therapy', European Psychiatry 25, 839. https://doi.org/10.1016/s09249338(10)70830-0

Mitterschiffthaler, M.T., Fu, C.H.Y., Dalton, J.A., Andrew, C.M. \& Williams, S.C.R., 2007, 'A functional MRI study of happy and sad affective states induced by classical music', Human Brain Mapping 28(11), 1150-1162. https://doi.org/10.1002/ hbm. 20337

Nilsson, U., Unosson, M. \& Rawal, N., 2005, 'Stress reduction and analgesia in patients exposed to calming music postoperatively', European Journal of Anaesthesiology 22(2), 96-102. https://doi.org/10.1017/s0265021505000189

Oelkers-Ax, R., Leins, A., Parzer, P., Hillecke, T., Bolay, H.V., Fischer, J. et al., 2008 'Butterbur root extract and music therapy in the prevention of childhood migraine: An explorative study', European Journal of Pain 12(3), 301-313. https:// doi.org/10.1016/j.ejpain.2007.06.003

Omar, R., Henley, S.M.D., Bartlett, J.W., Hailstone, J.C., Gordon, E., Sauter, D.A. et al., 2011, 'The structural neuroanatomy of music emotion recognition: Evidence from frontotemporal lobar degeneration', Neurolmage 56(3), 1814-1821. https://doi. org/10.1016/j.neuroimage.2011.03.002

Pereira, C.S., Teixeira, J., Figueiredo, P., Xavier, J., Castro, S.L. \& Brattico, E., 2011, 'Music and emotions in the brain: Familiarity matters', PLoS One 6(11), e27241. https://doi.org/10.1371/journal.pone.0027241

Peretz, I., Gaudreau, D. \& Bonnel, A.M., 1998, 'Exposure effects on music preference and recognition', Memory \& Cognition 26(5), 884-902. https://doi.org/10.3758/ bf03201171

Pert, C.B., 1997, Molecules of emotion: Why you feel the way you feel, Scribner, New York.

Pommerville, J.C., 2009, Alcamo's fundamentals of microbiology: Body systems, Jones \& Bartlett Learning, Sudbury, MA.

Porter, J., 2008, The Psions' guide, Lulu Inc., Raleigh, NC.

Pretorius, M., 2011, 'Sound: Conceivably the creative language of god, holding all of creation in concert', Verbum et Ecclesia 32(1). https://doi.org/10.4102/ve. v32i1.485

Raglio, A., Attardo, L., Gontero, G., Rollino, S., Groppo, E. \& Granieri, E., 2015, 'Effects of music and music therapy on mood in neurological patients', World Journal of Psychiatry 5(1), 68-78. https://doi.org/10.5498/wjp.v5.i1.68

Reck, D.D., 1997, Music of the whole earth, De Capo Press, Boston, MA.

Risch, M., Scherg, H. \& Verres, R., 2001, 'Music therapy for chronic headaches. Evaluation of music therapeutic groups for patients suffering from chronic headaches', Schmerz 15(2), 116-125.

Salimpoor, V.N., Benovoy, M., Larcher, K., Dagher, A. \& Zatorre, R.J., 2011, 'Anatomically distinct dopamine release during anticipation and experience of peak emotion to music', Nature Neuroscience 14(2), 257-262. https://doi.org/10.1038/nn.2726

Särkämö, T., Ripollés, P., Vepsäläinen, H., Autti, T., Silvennoinen, H.M., Salli, E. et al., 2014, 'Structural changes induced by daily music listening in the recovering brain after middle cerebral artery stroke: A voxel-based morphometry study', Frontiers in Human Neuroscience 8, 245. https://doi.org/10.3389/fnhum.2014.00245 
Särkämö, T., Tervaniemi, M., Laitinen, S., Forsblom, A., Soinila, S., Mikkonen, M. et al., 2008, 'Music listening enhances cognitive recovery and mood after middle cerebral 2008, 'Music listening enhances cognitive recovery and mood after middle cer
artery stroke', Brain 131(3), 866-876. https://doi.org/10.1093/brain/awn013

Satoh, M., Nakase, T., Nagata, K. \& Tomimoto, H., 2011, 'Musical anhedonia: Selective loss of emotional experience in listening to music', Neurocase 17(5), 410-417. https://doi.org/10.1080/13554794.2010.532139

Scarantino, B.A., 1987, Music power: Creative living through the joys of music, Dodd, Mead and Company, New York.

Siedliecki, S.L. \& Good, M., 2006, 'Effect of music on power, pain, depression and disability', Journal of Advanced Nursing 54(5), 553-562. https://doi.org/10.1111/ j.1365-2648.2006.03860.x

Slavich, G.M. \& Cole, S.W., 2013, 'The emerging field of human social genomics', Clinical Psychological Science 1(3), 331-348. https://doi.org/10.1177/216770 2613478594

Stebnicki, M., 2008, Empathy fatigue: Healing the mind, body, and spirit of professional counselors, Springer Publishing, New York.

Teng, X.F., Wong, M.Y. \& Zhang, Y.T., 2007, 'The effect of music on hypertensive patients', Conference Proceedings: Annual International Conference of the IEEE Engineering in Medicine and Biology Society 2007, 4649-4651. https://doi. org/10.1109/IEMBS.2007.4353376

Thompson, F.T., 2014, Music in the social and behavioral sciences: An Encyclopedia, SAGE Publications, Thousand Oaks, CA.
Three Initiates, 1908, The Kybalion: A study of the hermetic philosophy of ancient Egypt and Greece, 1st edn., Yoga Publication Society, Ahmedabad, Gujarat, India.

Van Deventer, V. \& Mojapelp-Batka, M., 2013, A students A-Z of psychology, 2nd edn., Juta Academic, Cape Town.

Vantomme, J., Balaban, M., Ebcioglu, K. \& Laske, O., 1994, 'Understanding music with Al: Perspectives on music cognition', Computer Music Journal 18(1), 81. https:// doi.org $/ 10.2307 / 3680524$

Wallis-Budge, E.A., 1969 [1904], The Gods of the Egyptians Vol. 1, Dover Publications, New York.

Watanabe, Y., 2012, 'New findings on the underlying neural mechanism of emotion induced by frightening music', Journal of Nuclear Medicine 53(10), 1497-1498. https://doi.org/10.2967/jnumed.112.109447

Wimberly, A.S., 1997, 'Music and the promotion of healing in religious caregiving', The Journal JJTC 25(2), 99-124.

Yates, F., 1991, Giordano Bruno and the Hermetic tradition, University of Chicago Press, Chicago, IL.

Zhang, Y., Chen, Q., Du, F., Hu, Y., Chao, F., Tian, M. et al., 2012, 'Frightening music triggers rapid changes in brain Monoamine receptors: A pilot PET study', Journal of Nuclear Medicine 53(10), 1573-1578. https://doi.org/10.2967/ jnumed.112.106690 